\section{War and the Austrian School: Modern Austrian economists take on aggressive wars}

William L. Anderson, Scott A. Kjar, and James D. Yohe

$\mathrm{E}$ arly Austrian economists, exemplified by Menger, Böhm-Bawerk, and Wieser, were known for their emphasis on marginal analysis, money, capital structure, time horizons, and alternative cost. A subsequent generation, led by Mises and Hayek, enriched that analysis in myriad ways, including an increased focus on the structure of production, the distorting effects of monetary policy, and an understanding of the role played by societal and governmental institutions. These key scholars and their ideas play an important role in understanding the Austrian school's views on both the economics of war and the economic consequences of war. ${ }^{1}$

What's more, the Austrians see effects emanating from the structure of production not only on an economy but on civilization itself, as well as on specific cultures. As noted by Menger, Böhm-Bawerk, Hoppe, and others, economic development is a civilizing force. As entrepreneurs expand the matrix of capital and increase infrastructure, they extend the range over which trade occurs. Further, by necessity, economic development extends the time horizons of entrepreneurs who look ever farther into the future to project consumer demand, production methods, costs, and revenues. This leads to a better understanding of the societies and cultures involved in trade, thereby reducing overall tensions. Thus, the expansion of trade drives both a higher standard of living at home and an increased awareness of the abroad. Hence, trade is a civilizing force.

During war, the emphasis on short-term destruction rather than long-term production has exactly the opposite set of effects. Instead of entrepreneurs concerning themselves with how best to meet the future needs of domestic and foreign markets and, hence, how best to structure the matrix of capital to maximum productive capacity in the long term, the focus is on how to force the existing matrix of capital to fit a short-term goal of maximum destruction. Instead of consumers and entrepreneurs looking after their own long-term goals, they look after the short-term ends of political and military leaders. Likewise, rather than being concerned about what other cultures believe and want, entire societies become concerned with destroying those other cultures and their beliefs. In other words, in the Austrian view, war is destructive to civilization itself, as well as to local cultures.

Since World War II, a third generation of Austrian economists has continued to develop and expand these Austrian ideas, often in ways even more explicitly antiwar than did the previous generations. This is not to say that Austrians are necessarily pacifists. No less an antiwar activist than Murray N. Rothbard believed in "just war" theory. However, the literature since World War II makes clear that Austrians do not hesitate to criticize governments for engaging in warfare. This article discusses examples of relevant contributions made by this third generation of Austrians.

\section{Henry Hazlitt on opportunity cost}

At the heart of Austrian opposition to war is the simple economic concept of opportunity cost. Perhaps no Austrian has demonstrated the power of opportunity cost more than Henry Hazlitt, whose Economics in One Lesson is often cited by Austrians as a very good practical guide to economic thinking in general. According to Hazlitt, "The art of economics consists in looking not merely at the immediate but at the longer effects of any act or policy; it consists in tracing the consequences of that policy not merely for one group but for all people.”2

Throughout the entire book, Hazlitt stresses the idea that each time one outcome occurs, some other outcome is foregone. For example, in the well-known broken window fallacy, if a hoodlum breaks a store window, thereby causing a shopkeeper to buy a new window, the shopkeeper is now unable to purchase a new suit. The new business generated for the glazer is exactly met by the lost business to the tailor. Absent the hoodlum's act, society would have had both a window and a new suit; following the act of destruction, society will have a new window, but not the suit. Thus, the cost of the act is not only the broken window, but the suit that will never come into existence. This lesson is the foundation for Hazlitt's explication of the economic effects of war.

Hazlitt devotes an ironic chapter to "The Blessings of Destruction," the idea that there are "almost endless benefits in enormous acts of destruction." It is easy to see a destroyed building - whether by act of war or act of nature, such as a hurricane or tornado - and then to imagine the jobs necessary to rebuild it. Construction work is highly visible, and even the most casual bystander can see the jobs created to rebuild things that have been destroyed. Anyone can see a destroyed building, and then see the new building that replaced it.

The energy needed to replace a single destroyed building is vastly multiplied by war: Entire cities are laid to waste, industrial sectors destroyed, and roads and bridges demolished. Those who commit the broken window fallacy-seeing only the new window without seeing the lost suit—commit the same fallacy on a grand scale here. There are thousands, or even millions, of workers mobilized to rebuild that which has been lost. Skilled and unskilled workers, managers, people engaged in transportation, people who make concrete and steel, those who fell timber, and more, all are visibly active in the rebuilding process. 
Yet all of those people and resources, absent the destruction, could have been turned toward other ends. During the time a destroyed refrigerator factory is being rebuilt, for example, the economy could instead have been producing actual refrigerators. Instead of rebuilding schools that have been destroyed in war, peacetime resources could have been directed toward educating children. As Hazlitt stresses, "Wherever business was increased in one direction, it was (except insofar as productive energies were stimulated by a sense of want and urgency) correspondingly reduced in another." ${ }^{3}$

Even the argument that the newly rebuilt factories and schools are somehow better or more efficient than those destroyed is not sufficient justification for the destruction. After all, if a new factory is better than the existing one, the factory owner can blow it up himself; if a new school is better than the existing one, the school board can tear it down and rebuild. If new efficiencies truly outweighed the costs of destruction, shop owners, factory owners, homeowners, and school boards would engage in the destruction themselves. War is not needed to accomplish such necessary destruction.

Hazlitt's analysis does not stop with the physical destruction. He points out, in the chapters "Public Works Mean Taxes" and “Taxes Discourage Production," that any costs government bears in rebuilding ultimately are born by taxpayers who already are bearing the costs of their own rebuilding. A homeowner whose home was destroyed now pays both for his own rebuilding and for the rebuilding of roads, bridges, police buildings, and other infrastructure projects. As taxes are raised to pay for such public works projects, entrepreneurship is weakened. The reason for this is that resources that might have been available to start new businesses or to expand existing ones are taxed away to support a government-directed rebuilding effort. But the higher the tax rate, the greater the disincentive for a prospective entrepreneur to create new projects that generate permanent jobs and long-term wealth. Thus, the rebuilding boom that occurs after war does not generate permanent prosperity. Rather, it generates the temporary appearance of prosperity at the cost of long-term wealth-building activities. We thus come to see the "blessings" of destruction in at least three ways: (1) as actual destruction during the war; (2) as resource shifts away from consumer and societal needs toward war goods production during war; and (3) as entrepreneurial disincentives and resource shifts away from long-tem wealth production after war.

Robert Higgs on crises and their effects on the size of government

Like Mises and Hayek, Robert Higgs (1987) examines government intervention, adding a focus on the growth of government during and after crises. In particular, he identifies wars and economic downturns as the primary periods during which the influence, scope, and power of government have substantially increased. Of particular importance to Higgs is his observation that when governments expand during a crisis, they rarely shrink to their prior size following its resolution. Instead, Higgs says, there is a "ratchet effect" of government intervention. It goes as follows:
- A crisis occurs (often created by the government itself, such as a war);

- government intervenes into economic and social affairs;

- the crisis ends; and

- some but not all of the government controls are lifted.

Higgs points out that during World War I, the United States government assumed powers clearly outside the realm of constitutional law. True, many wartime regulatory agencies like the Food Administration and the Railroad Administration were scrapped by the end of 1920, yet railroad and shipping regulations remained, and laws like the Espionage Act and the Trading with the Enemy Act were left intact. He also points out that "Wartime prohibition of alcoholic beverages, a purported conservation measure, transmogrified into the ill-fated 18th Amendment."

Government economic intervention during war also convinces people that such mobilization would work in peacetime. Higgs writes:

Most importantly, the dominant contemporary interpretation of the war mobilization, including the belief that federal economic controls had been instrumental in achieving the victory, persisted, especially among the elites who had played leading roles in the wartime economic management. ${ }^{5}$

Further, Higgs argues that much of the New Deal apparatus came from the economic controls imposed in World War I, citing the War Finance Corporation's reemergence as the Reconstruction Finance Corporation, the War Industries Board reappearing as the National Recovery Administration, the Food Administration as the Agricultural Adjustment Administration, and many more. ${ }^{6}$

Higgs's position - of the "success" of war being seen as a direct result of economic controls - is echoed by Anderson (1949) and Mises (1949), both of whom say that U.S. American economic controls in World War II retarded the output of weapons and war materiel. In fact, Higgs challenges the belief that World War II "brought the country out of the Great Depression.", Dealing with what he says is the "general consensus" among historians that the war was an economic success, he writes that relatively high GDP figures just reflected high military expenditure while ordinary consumers were far worse off than before. Without new cars and new spare parts, and with gasoline rationing, travel to work became difficult, forcing people to move to population centers. This, in turn, led to overcrowded housing, which was exacerbated by rent controls, creating disincentives for landlords to repair existing housing or build new housing. Many goods became unavailable, and black markets flourished, creating new costs involved in searching for goods in illegal markets, arranging trades using ration coupons, or standing in lines. He writes: "The government exhorted the public to 'use it up, wear it out, make it do, or do without.' In thousands of ways, consumers lost their freedom of choice.” ${ }^{8}$

As for the war's effect upon unemployment, which fell from double-digits to less 
Robert Higgs emphasizes that during World War II, the United States saw very little private sector investment and production and that the war did not produce an economic miracle as some have claimed. Austrian school economists argue that economic prosperity returned not because of the war but in spite of it.

Physical casualties included 405,399 dead and 670,846 wounded. To treat military jobs as commensurable with civilian jobs, as economists do in computing the tradeoffs between them, betrays a monumental obtuseness to their realities. ${ }^{9}$

In his paper on the "prosperity” of World War II, Higgs emphasizes that there was very little private investment and production during that time, as most of the economic production was directed toward war goods. The war did not produce the "economic miracle" that some have claimed. To further challenge the "war prosperity" thesis, only after the war, when government spending fell drastically, did real economic prosperity return. Writes Higgs:

By early 1945, almost everyone expected the war to end soon. The prospect of a peacetime economy electrified investors. Stock prices surged in 1945 and again in 1946. In just two years the Standard \& Poor's index increased by 37 percent and the value of all shares on registered exchanges by 92 percent, despite a decline of current-dollar after-tax corporate profits from their peak in 1944. Did people expect the end of “wartime prosperity” to be economically deleterious? Obviously not. $^{10}$

True, during the war there were jobs to be had on the home front, and while life was hard, people did have employment. But it was in producing war goods or in coordinating the war effort, neither of which can be consumed by ordinary people. (People cannot “consume” artillery shells or bombs dropped from 30,000 feet.) Although there can be some transference of the technologies of producing war goods to producing civilian goods, nonetheless a large portion of wartime capital is abandoned after the war is over, and World War II was no exception.

Austrian school economists emphasize that prosperity returned not because of World War II but in spite of it. Certainly, war goods capital could be sustained only for the duration of the war itself. Because the capital formation was meaningful solely because of its relation to war production, the only way for business owners to be able to direct production to civilian goods was either to abandon those producers' goods altogether or find a way to redirect them to other uses. Nonetheless, as Higgs so aptly points out, the perception — especially in the popular media — that World War II ended the Great Depression is still popular today. ${ }^{11}$ It is not a long step to imagine that "the equivalent of war spending” will bring economic prosperity, and it also is not a long step to believing that another war is just what an economy might need.

\section{Israel Kirzner on the role of the entrepreneur}

Kirzner (1973) argues that entrepreneurship springs from the basic idea of arbitrage: Entrepreneurs seek to buy low and sell high. Arbitrage not only includes finding a particular good at different prices in different markets, but includes finding factors of production at a price less than the discounted present value of the future price of the finished good. Following Menger (1994), the Austrian school sees a finished good and its factors of production (including entrepreneurship and time) as equivalent. Thus, an entrepreneur who buys factors, engages in production, and then sells the finished product at a profit has engaged in arbitrage, understood broadly: He bought (factors) low and sold (goods) high.

In the absence of a large government presence in the market, entrepreneurs are continually alert to shifting consumer sentiment. Goods that provide consumer satisfaction or fulfill Menger's "needs" in one era can become obsolete, either as the need becomes entirely fulfilled or as other products are introduced that can better fulfill those needs. Being alert to expected consumer desires as well as to resources available in the market, entrepreneurs stand ready to engage in productive arbitrage, removing resources from one allocation and placing them into another, higher-valued, allocation.

But during war, government's presence looms large in markets. Even setting aside issues of price controls, rationing, nationalization of key industries, and other common economic issues in war, the clear fact is that government's demand for war goods skyrockets. Entrepreneurs alert to changes in markets can see that profits have shifted out of consumer goods and into war goods. The Kirznerian arbitrage opportunity comes in, taking resources that otherwise would have been allocated to schools, houses, and consumer vehicles and shifting them toward munitions factories, barracks, and military vehicles. An increase in the number of men in uniform also drives other changes, such as a shift from packing soup in small cans for home consumption into packing soup into barrels for mess hall consumption. In the former case, subtle changes in taste might have huge impacts on profits; in the latter, sheer volume is the primary issue. Quality is expendable.

In peacetime, entrepreneurs likely seek sustainable projects that generate ongoing profits. In wartime, entrepreneurs likely see quick-profit projects that have no ability to generate profits once war is over. Thus, wars can distort entrepreneurial endeavors, 
because the Kirznerian entrepreneur, alert to changes in the economy, reacts predictably to changed incentives brought about by war. The entrepreneur shifts the economy's matrix of capital away from consumer goods and toward war goods. The societal cost, as always, lies not merely in the tax paid for war goods, but also in the foregone utility from consumer goods that are not created for the duration of the war.

Roger Garrison on capital and the structure of production

One area in which Austrian economists differ from the economic mainstream is in their views on capital and capital formation. Following Mises, Hayek, and Rothbard, Garrison (2001) emphasizes the intertemporal nature of capital formation, ${ }^{12}$ All of them note that capital structure (the matrix of capital) is embedded into an economy in a way that either can be sustained if capital investments follow real savings and spending patterns or, alternatively, is malinvested if capital formation cannot be sustained over time.

In this context, the concept of a societal time preference rate (TPR) lies at the heart of the Austrian understanding of capital. A society with a high TPR prefers its consumer goods sooner, while a society with a low TPR is willing to wait until later. A high-TPR society thus reduces its savings, drives up interest rates, and makes long-term capital-intensive production more expensive. In contrast, a low-TPR society reduces consumption, increases savings, and drives down interest rates, making long-term capital-intensive production less expensive. If a society changes its TPR, it therefore also drives changes in its long-term capital structure. The Austrian school refers to this as adding "orders of goods" to the process. A first-order good is a consumer good. Second-order goods directly make first-order goods. Third-order goods make second-order goods, and so forth. A lower TPR drives longer production processes and many higher orders of goods.

Garrison picks up the idea that capital is not merely a homogeneous blob that can be moved into and out of production processes at whim. A machine that makes candy bars is very different from a machine that makes shoes, even though both candy bars and shoes are consumer goods (lower-order goods). Likewise, a machine that mines coal is different from a machine that drills oil, even though both are extractive capital (higher-order goods). The candy machine and the oil drill are extremely different. An entrepreneur involved in capital formation, then, is involved in making a specific type of capital to perform a specific type of task at a specific time and in a specific place in a specific production process in anticipation of a specific future need.

Entrepreneurs who anticipate a future candy craze will develop and acquire different capital than will entrepreneurs who anticipate a future war. Entrepreneurs who anticipate a long, steady period of economic growth will develop goods further from consumers; those who anticipate uneven economic performance will focus on goods much closer to consumers. Entrepreneurial expectations of what will sell high in the near or far future thus drive the matrix of capital.
It takes time to develop a matrix of capital designed to provide maximum production of any good. Progressively higher orders of goods must be developed and produced, thereby lengthening the structure of production and increasing total output in the long term. However, as Mises noted, "War can only be waged with present goods." ${ }^{13}$ Once war starts, it is too late to begin the long-term changes necessary to engage in efficient production of war goods. Instead, the current structure of production must be modified to make do in order to turn out war goods immediately. This inefficient use leads to the consumption of an economy's capital, since machines are used in ways that are not quite what they were designed to do, and production schedules are rushed, thereby pushing equipment beyond the tolerances for which they were constructed. This ongoing consumption of capital will have its starkest appearance not during the war, but likely after the war, as it finally breaks down and decays beyond all repair. ${ }^{14}$

\section{Joe Salerno on the effects of wartime monetary policy}

Salerno (1999) notes that the economics of war involve both a "horizontal” and a "vertical” shift in resources and ties this explicitly to entrepreneurial error caused by monetary policy. Governments have three basic funding sources for war, and for all other government activities: taxation, borrowing, and money creation. ${ }^{15}$ Under normal, nonwar times, governments fund their activities with combinations of these three sources. Capital acquisition and investment by entrepreneurs occur within a given framework of government funding, e.g., if capital gains are taxed higher than is income, entrepreneurs have less incentive to engage in long-term projects, but if capital gains are taxed lower, or not at all, then entrepreneurs have more incentive to save current income to invest in projects that are sustainable in the long term.

With war, government's need for financing rises dramatically. Historically, governments have increased taxes_a fiscal "policy” measure_-although at least as far back as 1215, when renegade nobles forced King John of England to sign the Magna Carta, this has proven politically unpopular. ${ }^{16}$ Subsequently, governments tried monetary "policy," such as borrowing money by issuing war bonds. Bonds, whether for war or other purposes, are issued when a government runs a budget deficit and simply needs to borrow money. Myriad costs are associated with government bonds. As the Austrians see it, when government enters the market for loanable funds, it drives interest rates higher than they would otherwise be. Interest rates, in turn, cause changes in the matrix of capital. Government budget deficits thus lead to alterations in the market allocation of capital but in ways that are not always clear. If "crowding out" occurs, then there will be fewer firms creating fewer products and hiring fewer employees.

Since the advent of central banking and the corresponding monopoly to issue bank notes, the quickest and surest way for a government to generate funds needed for fighting wars has been via the printing press. Rather than merely causing changes in 
prices or in quantities of production and consumption, Austrians see a change in the money supply as causing a shift in investment patterns. If a monetary expansion drives interest rates below their free-market levels, entrepreneurs whose projects were previously not sufficiently profitable to allow them to be undertaken will now find that lower-priced money makes their projects feasible. Unfortunately, cheaper money does not mean that scarce resources themselves are any less scarce; instead, more projects now vie for the same resources, suggesting that any short-term increase in economic activity will be met by a long-term decline when these competing projects find that there are not enough resources to complete all of the projects, and many will have to be liquidated.

This analysis complements Salerno's argument about changes in the vertical structure of an economy. War goods themselves cause one set of changes to an economy's matrix of capital, while inflationary policies used to pay for them cause another set of changes to an economy's matrix of capital. Because both sets of changes are not viable in the long term, the economy is likely to be in worse shape following war than before or during war.

Further exacerbating the issue is the fact that a monetary inflation does not cause an equal price inflation at every level of every industry at the same time. Instead, some industries and individuals see the new money first, before prices have fully adjusted. Such individuals and industries have a net wealth gain because they can command more resources and goods before prices adjust. During wartime, the first recipients of the new money will be the war goods industries. Other industries and firms fall into the middle of the process and might see some prices rise before receiving the new money, therefore being in a slightly worse position. Still other people will be the last to receive the new money: They face the increased prices long before they receive increased wages. These people are made substantially worse off by the inflation, in effect suffering a wealth transfer away from them and toward the government and its preferred industries that received the new money first. Thus, inflation serves not only to distort production, it also serves as a hidden tax in that it transfers wealth from late recipients to early recipients and to the government itself.

Murray Rothbard on "just war" theory

Since before the days of Adam Smith, economists of many schools and political persuasions have crossed academic boundaries in search of truth. John Locke might be best known for his work on political philosophy, but his ideas were closely related to his views on economics. John Stuart Mill wrote on such topics as philosophy, logic, race relations, and sexual equality, seeing them all as woven into his economics. William Stanley Jevons wrote on logic, the scientific methods, social reform, and other topics, in addition to his renowned work in theoretical and applied economics. Gunnar Myrdal studied race relations and economics and was a Member of Parliament in Sweden. Gary Becker tied economic analysis to drug addiction, crime, family structures, and more. Myriad other examples could be drawn showing the interdisciplinary work of many leading economists.

Murray N. Rothbard, dean of the Austrian school of economics during the last quarter of the twentieth century, worked in this interdisciplinary tradition. With multivolume works on U.S. history, the history of economic thought, and political economy, and with books on ethics, political theory, and economic theory, Rothbard found it impossible to discuss any issue solely within the confines of one academic field, such as economics. Rather, to discuss a topic such as war, Rothbard drew on many fields, including economics, history, ethics, and political philosophy.

Calling himself an Austro-libertarian, Rothbard (1998; 2002) opposed nearly all wars on two grounds. First, as an issue of political economy, war increases the amount and effects of government coercion. On the latter, Rothbard accepts the view put forward by Randolph Bourne that "war is the health of the state." ${ }^{17}$ Second, as a moral or ethical issue, in most instances, war is unjust. The issue of a just war is important in understanding Rothbard, who writes that "a just war exists when a people tries to ward off a threat of coercive domination by another people, or to overthrow an already existing domination.” In essence, Rothbard would view any attempt by nonstate or state actors to repel the use of force as just. Revolutions and defensive wars are just, offensive wars are unjust. Yet, according to Rothbard, as “even a just war cannot be entered into lightly; an unjust one must therefore be anathema."18

Just war theory is hardly new, and Rothbard draws heavily on such 16th-century Spanish scholastics as Franscisco de Vitoria, who founded the philosophical School of Salamanca, and Francisco Suarez, a natural law theorist and early writer on international law. Likewise, Rothbard follows Dutch natural law theorist Hugo Grotius, who argued three ways in which a war might be considered just: (1) to engage in self-defense (but not to aggress), (2) to garner restitution (but not to loot), and (3) to punish. Further, Grotius argued that all parties to a war, whether just or not, are bound by a civilized code of conduct that existed into the 19th century. (Clearly, recent events such as the United States engaging in "enhanced interrogation methods" at Guantanamo fall outside of Grotius's code.)

Rothbard notes that the classical international lawyers, writing during the rise of the nation-state, recognized that it was folly to try to ban war, the position "that has been dominant since 1914, by the dominant partisans of the League of Nations and the United Nations." ${ }^{19}$ Rather than take such a utopian and naive view, the classical theorists sought instead to contain and limit the state. According to Rothbard, classical international lawyers were successful in getting nations to adopt two key points. First,

... above all, don't target civilians. If you must fight, let the rulers and their loyal or hired retainers slug it out, but keep civilians on both sides out of it as much as possible. The growth of democracy, the identification of citizens with the state, conscription, and the idea of a "nation in arms," all whittled away this excellent tenet of international law. ${ }^{20}$ 
Rothbard would take this concept of not targeting civilians on either side one step further. "War, then, even a just, defensive war, is only proper when the exercise of violence is rigorously limited to the individual criminals [the aggressor]." 21 The implications of this tenet of Rothbard's thought would counter the justifications of the Bush administration which claimed that the war in Afghanistan was defensive in nature, and therefore just. One civilian death would counter the just war tag of any act whether considered offensive or defensive.

This leads Rothbard to view the use of nuclear weapons, and other similar devices as unjust, even in a defensive war.

It has often been maintained, especially by conservatives, that the development of horrendous modern weapons of mass murder (nuclear weapons, rockets, germ warfare, etc.) is only a difference of degree rather than kind from the simpler weapons of an earlier era. Of course, one answer to this is that when the degree is the number of human lives, the difference is a very big one. But a particular libertarian reply is that while the bow and arrow, even the rifle, can be pinpointed, if the will be there, against actual criminals, modern nuclear weapons cannot. Here is a crucial difference in kind. Of course, the bow and arrow could be used for aggressive purposes, but it could also be pinpointed to use only against aggressors. Nuclear weapons, even "conventional” aerial bombs, cannot be. These weapons are ipso facto engines of indiscriminate mass destruction. (The only exception would be the extremely rare case where a mass of people who were all criminals inhabited a vast geographical area.) We must, therefore, conclude that the use of nuclear or similar weapons, or the threat thereof, is a crime against humanity for which there can be no justification. ${ }^{22}$

The second tenant of classical international law theory was that the rights of neutral states should be recognized. This is opposed to the modern notion that

... "neutrality" has been treated as somehow deeply immoral. Nowadays, if countries A and B get into a fight, it becomes every nation's moral obligation to figure out, quickly, which county is the "bad guy," and then if, say, A is condemned as the bad guy, to rush in and pummel A in defense of the alleged good guy $\mathrm{B}^{23}$

We see this played out in the "war on terrorism.” The U.S. government pressured other states to enter the war on its side. The U.S. judged Iraq and Afghanistan guilty, and then demanded that all other nations do the same. States that so joined, such as Saudi Arabia, were considered American allies, regardless of any ties that might have existed between its government and those very terrorists who are being sought. In contrast, states that refused to join — those that sought to maintain neutrality-such as France or Germany, were accused of being pro-terrorist and anti-American.

\section{Conclusion}

The modern Austrian school's position is neither prowar nor antiwar per se. As Rothbard notes in his just war analysis, in some instances, it is appropriate to fight defensively. However, the Austrian are opposed to aggressive wars.

The Austrian school builds from its fundamental tenets to derive its general antiwar (or non-prowar) stance. From its views on scarcity, utility, the origins and derivation of money, the nature of capital, and the role of the entrepreneur, the Austrian view is a well-integrated economic position that has clear and obvious application to the question of war.

This position grows out of the unique Austrian application of opportunity cost and its implications on the structure of production. Thus, the Austrians are concerned not only about the short-term effects during war but also about the long-term effects generated by the alteration in the matrix of capital, effects that are worsened as a war is lengthened. By shifting the attention of entrepreneurs away from consumer desires and toward government desires, war drives changes in both horizontal and vertical economic domains that are damaging to consumers. The increased role of intrusive government has effects on the relations between and among money, interest, capital, and consumer goods that are short-term and long-term in their implications.

John Denson's The Costs of War (1999) is subtitled “America's Pyrrhic Victories.” It makes the point that any short-term benefits from war are more than offset by long-term costs. Denson notes that in 280 B.C. and 279 B.C., Pyrrhus defeated the Romans and sent them into retreat. However, the costs of Pyrrhus's wins were greater than the benefits, and in the long term, Pyrrhus was destroyed. To the Austrians, this is always the problem with aggressive war: Regardless of which side wins, the people on both sides lose, and in the long term, even the victor will be destroyed by the inexorable economics of war.

\section{Notes}

William L. Anderson, the corresponding author, is a professor of economics at Frostburg State University in Frostburg, MD, USA. He may be reached at <banderson@frostburg.edu>. Scott A. Kjar is in Las Vegas, NV, USA, and James D. Yohe is a professor of economics at Gadsden State College, Gadsden, AL, USA

1. This article is the last in a trilogy on contributions by the Austrian school of economists on questions of war and peace. See Kjar and Anderson (2010) and Westley, Anderson, and Kjar (2011).

2. Hazlitt (1996, p. 5).

3. Hazlitt (1996, p. 15). 
4. Higgs (1999, p. 27).

5. Higgs (1999, p. 27).

6. Higgs (1987, pp. 154-156).

7. Higgs (1992; 1997a; 1997b).

8. Higgs (1992, pp. 52-53).

9. Higgs (1992, p. 43).

10. Higgs (1992, p. 58).

11. McCardle (2009), Smiley (2008), Library of Congress (n/d.).

12. Mises (1949), Hayek (2008), Rothbard (1962).

13. Mises (1983, p. 163). George W. Bush’s Secretary of Defense, Donald Rumsfeld, made a similar statement: "You go to war with the army you have." See Kaplan (2004).

14. Schumpeter (1991).

15. Rothbard (1992).

16. Thorne (1965).

17. Bourne (1964).

18. Rothbard (1999, p. 119).

19. Rothbard (1999, p. 120).

20. Rothbard (1999, p. 120).

21.Rothbard (1998, p. 190).

22. Rothbard (1998, pp. 190-191).

23. Rothbard (1998, p. 120).

\section{References}

Anderson, B. 1949, Economics and the Public Welfare: A Financial and Economic History of the United States. Princeton, NJ: D. van Nostrand Company.

Bourne, R. 1964. War and the Intellectuals. New York: Harper and Row.

Denson, J., ed. 1999. The Costs of War: America's Pyrrhic Victories. 2nd exp. ed. New Brunswick, NJ: Transaction Publishers.

Garrison, R. 1984. “Time and Money: The Universals of Macroeconomic Theorizing.” Journal of Macroeconomics. Vol. 6, No. 2, pp. 197-213.

Hayek, F.A. 2008. Prices and Production and other Works: F.A. Hayek on Money, the Business Cycle, and the Gold Standard. Auburn, AL: Ludwig von Mises Institute.

Hazlitt, H. 1996. Economics in One Lesson. San Francisco, CA: Fox \& Wilkes.

Higgs, R. 1987. Crisis and Leviathan: Critical Episodes in the Growth of American Government. New York: Oxford University Press.

Higgs, R. 1992. "Wartime Prosperity? A Reassessment of the U.S. Economy in the 1940s.” Journal of Economic History. Vol. 52, No. 1, pp. 41-60.

Higgs, R. 1997a. "Regime Uncertainty: Why the Great Depression Lasted So Long and Why Prosperity Resumed after the War.” The Independent Review. Vol. 1, No. 4, pp. 561-590.

Higgs, R. 1997b. "War and Leviathan in Twentieth-Century America: Conscription as the Keystone,” pp. 375-388 in J.V. Denson, ed. The Costs of War: America's Pyrrhic Victories. New Brunswick, NJ: Transaction Publishers.

Higgs, R. 1999. "How War Amplified Federal Power in the Twentieth Century.” The Freeman. Vol. 49, No. 7, pp. 26-29.

Kaplan, F. 2004. "Rumsfeld vs. the American Soldier." http://www.slate.com/id/2110818/ [accessed 5 March 2009].

Kirzner, I. 1973. Competition and Entrepreneurship. Chicago, IL: The University of Chicago Press.

Kjar, S.A. and W.L. Anderson. 2010. "War and the Austrian School: The Economics of the Founders.” The Economics of Peace and Security Journal. Vol. 5, No. 1, pp. 6-11.

Library of Congress. Undated (n/d). “America’s Story from America's Library: Depression and WWII.” http://www.americaslibrary.gov/jb/wwii/ jb_wwii_subj.html [accessed 12 June 2011].

McCardle, M. 2009. “Did World War II End the Great Depression?” http://www.theatlantic.com/business/archive/2009/02/did-world-war-ii-end-the -great-depression/4724/ [accessed 12 June 2011].

Menger, C. 1994. Principles of Economics. Trans. James Dingwall and Bert F. Hoselitz. Grove City, PA: Libertarian Press.

Mises, L. 1949. Human Action: A Treatise on Economics. New Haven, CT: Yale University Press. 
(C) www.epsjournal.org.uk - Vol. 7, No. 1 (2012)

Mises, L. 1983. Nation, State, and Economy: Contributions to the Politics and History of our Time. Trans. L.B. Yeager. New York: New York University Press. Rothbard, M.N. 1962. Man, Economy, and State. Auburn, AL: Ludwig von Mises Institute.

Rothbard, M.N. 1992. "How and How Not to Desocialize.” The Review of Austrian Economics. Vol. 6, No. 1, pp. 65-77.

Rothbard, M.N. 1997. The Logic of Action. Northampton, MA: Edward Elgar.

Rothbard, M.N. 1998. The Ethics of Liberty. New York: New York University Press. Rothbard, M.N. 1999. “America’s Two Just Wars: 1775 and 1861,” pp. 119-132 in J.V. Denson, ed. The Costs of War: America's Pyrrhic Victories. New Brunswick, NJ: Transaction Publishers.

Rothbard, M.N. 2002. A History of Money and Banking in the United States. Auburn, AL: Ludwig von Mises Institute.

Salerno, J.T. 1999. "War and the Money Machine: Concealing the Costs of War Beneath the Veil of Inflation,” pp. 443-454 in J.V. Denson, ed. The Costs of War: America's Pyrrhic Victories. New Brunswick, NJ: Transaction Publishers.

Schumpeter, J.A. 1991. "The Crisis of the Tax State,” in R. Swedberg, ed. The Economics and Sociology of Capitalism. Princeton, NJ: Princeton University Press.

Smiley, G. 2008. “Great Depression.” The Concise Library of Economics. http://www.econlib.org/library/Enc/GreatDepression.html [accessed 12 June 2011].

Thorne, S.E. 1965. "What Magna Carta Was,” pp. 3-19 in S.E. Thorne, et al. The Great Charter: Four Essays on Magna Carta and the History of our Liberty. New York: New American Library.

Westley, C., W.L. Anderson, and S.A. Kjar. 2011. "War and the Austrian School: Ludwig von Mises and Friedrich von Hayek.” The Economics of Peace and Security Journal. Vol 6, No. 1, pp. 28-34. 